\title{
PERANAN PEMBERIAN MAKANAN TAMBAHAN PADA ANAK UMUR 6 - 23 BULAN PADA SAAT KRISIS EKONOMI
}

\author{
Sandjaja'; Sri Mulyati'; M. Saidin'; Suhartato' dan Yekti Widodo ${ }^{1}$ \\ ${ }^{1}$ Peneliti di Puslitbang Gizi dan Makanan, Bogor
}

\section{ABSTRACT
THE IMPACT OF FOOD SUPPLEMENTATION FOR CHILDREN AGED 6-23 MONTHS DURING ECONOMIC CRISIS

Supplementary feeding program (PMT) for children aged 6-23 months of poor families (Gakin) is a sub-component of Social Safety Net - Health Sector (SSN-HS) following economic crisis that hit Indonesia the end of 1997. It is intended to provide additional food and prevent deteriorating impact of nutritional status of the target. The main objective of the study was to determine the impact of PMT for children on malnutrition and growth as compared with that for children not receiving PMT. The design of the study is case control. Case was children of poor family who had or ever had received PMT for three months provided by SSN-HS in the last six months. Control was children of near poor families but who had never received PMT. Matching criteria for case and control were age, sex, and residence of the family. The study was conducted in West Java, Central Java, South Kalimantan covering 1014 cases and 1014 controls and their families. Data on child collected were current weight and height, and retrospective weight in the last 10 months. Other data collected were characteristics of chlidren and therir families including socioeconomic status, clinical examination, dietary intake including food suplement. Program implementation of PMT varied among study areas on selection criteria for child beneficiaries in addition to poor families, duration of PMT, method of distribution, type of food. There were similar characteristics between case and control in age, sex, breastfeeding, morbidity except for socioeconomic status of the family, age of father, educational attainment of parents. Foods distributed for 6-11 month old samples included supplementary food, foodstuff, cooked (rice/flour porridge+egg). Foods for 1223 month old samples more varied than food suplement for 6-11 months old children. Nutrient content of food distributed was $268 \mathrm{Kcal}$ for energy and 9.2 grams protein, below the recommended nutrient content of PMT 360-430 Kcal and 9-15 grams protein. Dietary intake were similar in both groups consisting of energy around $46 \%$ RDA and protein $67-73 \%$ RDA (excluding breast milk). This finding shows that part of PMT became substitute rather than supplement. Cases had significantly lower nutritional status in W/A and $\mathrm{H} / \mathrm{A}$ anthropometric indices than control except for W/H. Growth pattern as analyzed using retrospective data found that there was faltering growth pattern in both groups. Period between three months prior to PMT to the baseline showed that more decreasing Z-score was significantly (repeated measures of ANOVA) greater in case than in control group. Three months during PMT, there was still further decreasing mean Z-score in both groups although it was not as great as three months before. This finding showed that PMT was able to prevent deteriorating nutritional status among child beneficiaries of poor families but was not able to improve their nutritional status.

Keywords: food suplementation, economic crisis

\section{PENDAHULUAN}

risis ekonomi yang melanda Indonesia sejak akhir tahun 1997 yang diikuti dengan ketidak stabilan politik selama masa transisi mengakibatkan dampak pada berbagai bidang kehidupan masyarakat. $\mathrm{Di}$ bidang ekonomi terjadi penurunan pendapatan per kapita yang cukup drastis. Beberapa penyebabnya adalah depresiasi 
nilai mata uang rupiah yang menurun drastis dari Rp 2.500,- menjadi Rp.11.000,- per US dollar, kenaikan harga barang kebutuhan pokok, penurunan tingkat pendapatan riil khususnya pada golongan bawah, kegiatan ekonomi yang memburuk baik makro maupun mikro, terhambatnya aliran modal dan jaringan distribusi barang dan jasa, pemutusan hubungan kerja. Gelombang dampak krisis ekonomi tersebut bergulir terus dari tingkat makro yang terus bergerak ke sektor-sektor mikro sehingga terjadi stagnasi perekonomian rakyat.

Angka kemiskinan yang masih tinggi pada tahun 1976 yaitu sebesar $40.08 \%$ (54.2 juta penduduk) dalam dua dasawarsa dapat diturunkan secara drastis menjadi $11.34 \%$ (22.5 juta penduduk) pada tahun 1996 dan menurun lagi menjadi 21.5 juta penduduk tahun 1997. Penurunan angka kemiskinan ini sejalan dengan perbaikan indikator sosial lainnya seperti pendidikan dan kesehatan. Tetapi pada Desember 1998 angka kemiskinan meningkat lagi menjadi $24.23 \%$ (49.5 juta penduduk), atau meningkat 27 juta penduduk akibat krisis ekonomi (1,2). Kenaikan angka kemiskinan ini sebagai akibat dari transient poverty yang lebih disebabkan oleh imbas kenaikan harga dan penurunan pendapatan riil dan daya beli walaupun kemiskinan struktural masih cukup tinggi. Dampak peningkatan angka kemiskinan tersebut lebih terasa di perkotaan dibandingkan di perdesaan. Di sektor lapangan kerja, dampak krisis ekonomi telah menyebabkan 22 juta tenaga kerja kehilangan pekerjaannya akibat pemutusan hubungan kerja.

Akibat tingkat kemiskinan yang melanda Indonesia, tingkat konsumsi masyarakat menurun atau beralih ke konsumsi yang lebih buruk. Konsumsi beras selama krisis relatif konstan tetapi kualitas yang dikonsumsi mengalami penurunan ${ }^{(2)}$.

Data Pemantauan Konsumsi Gizi (PKG) menunjukkan bahwa konsumsi energi dan protein tidak mengalami perubahan nyata berkisar antara $2150 \mathrm{Kkal}$ dan 46 gram protein, tetapi terjadi peningkatan jumlah rumahtangga defisit energi dan protein.
Konsumsi makanan hewani sebagai sumber protein seperti daging, telur, dan buahbuahan menurun dan beralih ke konsumsi ikan yang diawetkan (asin), protein nabati, sayuran ${ }^{(3)}$. Padahal konsumsi protein hewani masih di bawah kecukupan yang dianjurkan. Kalau konsumsi daging per kapita per tahun pada 1996 sebanyak 8.41 $\mathrm{Kg}$, angka tersebut menurun menjadi 7.95 $\mathrm{Kg}$ (1997) dan $7.34 \mathrm{Kg}$ (1998). Konsumsi susu menurun dari $5.72 \mathrm{Kg}$ (1996), menjadi $5.25 \mathrm{Kg}(1997)$ dan $5.10 \mathrm{Kg}(1998)^{(2)}$.

Penurunan kualitas dan kuantitas makanan penduduk terutama pada golongan miskin berakibat pada penurunan tingkat kesehatan dan gizi terutama pada golongan rawan yaitu balita, ibu hamil, dan ibu menyusui. Data Susenas tahun 1989, 1992, 1995, 1998 menunjukkan trend penurunan prevalensi Kurang Energi Protein (KEP) pada balita berturut-turut $47,8 \%, 41,7 \%, 35,0 \%$ dan $32,5 \%$ (4). Hal ini berarti terjadi penurunan prevalensi KEP antar tahun sebesar $6,1 \%, 6,7 \%$, dan 2,5\%. Terlihat bahwa penurunan prevalensi pada dari tahun 1995-1998 hanya sebesar 2,5\%, masih jauh dari harapan. Bahkan prevalensi KEP pada anak umur 6-23 bulan pada tahun 1998/1999 lebih tinggi dibandingkan dengan tahuntahun sebelumnya ${ }^{(5)}$. Temuan tentang marasmus atau kwashiorkor sebagai bentuk KEP paling berat banyak dilaporkan dari berbagai wilayah di Indonesia. Prevalensi KEP tingkat berat tahun 1998 sebesar 4,2\% (4). Hal ini berarti sekitar satu juta balita menderita gizi buruk yang berperan dalam loss of generation.

Malnutrisi dan defisiensi zat gizi mikro berkontribusi terhadap peningkatan kematian, morbiditas yang diakibatkan oleh berbagai infeksi, berat bayi lahir rendah (BBLR), gangguan pertumbuhan, kognitif, penglihatan dan menurunnya kekebalan tubuh terhadap penyakit ${ }^{(6)}$.

Keuangan pemerintah dalam masa krisis juga sangat terbatas, sehingga terpaksa mengurangi dukungannya terhadap pelayanan dasar di bidang sosial. Gangguan dalam upaya pelayanan di bidang kesehatan dan sosial akan dibayar mahal 
untuk jangka waktu lama. Krisis ekonomi pada kelompok penduduk miskin dan rawan kesehatan akan berdampak lama.

Dalam rangka mengantisipasi krisis ekonomi dan berbagai konsekuensi yang diakibatkannya, pemerintah bersama beberapa lembaga bantuan membentuk 'Jaring Pengaman Sosial' (JPS) untuk masyarakat yang terkena dampak krisis paling berat. Komponen JPS bidang kesehatan (JPS-BK) meliputi pelayanan kesehatan dasar, pelayanan kebidanan dasar, program pemberian makanan tambahan (PMT), dan kegiatan-kegiatan penunjang lainnya bagi keluarga miskin (Gakin). Pemberian makanan tambahan sebagai salah satu sub komponen JPS-BK baik untuk bayi umur 6-11 bulan maupun anak umur di bawah dua tahun (12-23 bulan) Gakin sangat menentukan dalam upaya pencegahan makin memburuknya status gizi dan konsekuensi lanjutannya. Namun demikian dampak positif (keuntungan) dari PMT terhadap pertumbuhan anak perlu diteliti karena dampaknya tergantung pada berbagai faktor antara lain substansi paket yang diberikan, frekuensi dan waktu pemberian, efektifitas dan efisiensi pelaksanaannya.

Penelitian ini secara umum bertujuan untuk menilai dampak PMT Pemulihan untuk anak baduta umur 6-23 bulan terhadap status gizi anak. Tujuan khusus adalah untuk mengetahui perbedaan status gizi dan pola pertumbuhan antara anak baduta yang diberi PMT pemulihan dibandingkan dengan yang tidak mendapatkan PMT.

\section{BAHAN DAN CARA}

Desain penelitian adalah case-control. Case didefinisikan sebagai anak yang sedang/pernah mendapat PMT Pemulihan dari JPS-BK saja dan kontrol adalah anak yang tidak mendapat PMT. Matching antara case dan control dilakukan pada karakteristik umur, jenis kelamin, dan karakteristik keluarga. Karena kesulitan matching anak dari Gakin sebagai kontrol, diambil anak sebagai kontrol dari keluarga bukan Gakin yang mirip dengan Gakin dan tidak mendapatkan PMT. Kriteria tambahan untuk case dan kontrol adalah adanya catatan lengkap penimbangan berat badan di Posyandu.

Penelitian dilakukan di tiga Propinsi yaitu Jawa Barat, Jawa Tengah dan Kalimantan Selatan, delapan kabupaten yang dipilih secara purposive berdasarkan banyaknya Gakin, dan proporsi dana untuk PMT. Dari ketujuh kabupaten terpilih 135 desa yang merupakan 22 wilayah Puskesmas di 18 kecamatan.

Data yang dikumpulkan adalah status gizi anak dengan pengukuran berat badan, panjang badan saat penelitian dan data retrospektif berat badan selama 9 bulan terakhir, data kesehatan anak, PMT, recall konsumsi makanan anak dan sosial ekonomi keluarga. Selain itu data sekunder tentang keragaan pelaksanaan PMT juga dikumpulkan.

Sampel case adalah anak umur 8-30 bulan yang sedang atau pernah mendapat PMT Pemulihan dari JPS-BK pada saat mereka berumur 6-23 bulan. Sampel kontrol adalah anak dengan umur dan jenis kelamin sama yang tidak mendapat PMT. Sampel pengelola PMT adalah TPG/Kepala Puskesmas, bidan di desa dan kader Posyandu.

\section{HASIL DAN BAHASAN}

Hasil penelitian didapatkan dari 2028 anak, 1014 penerima PMT dan 1014 kontrol dengan rincian umur seperti terlihat dalam Tabel 1.

Tabel 1

Proporsi Anak Dengan PMT dan Non PMT Menurut Kelompok Umur 


\begin{tabular}{|c|c|c|c|}
\hline \multirow{2}{*}{$\begin{array}{c}\text { Kelompok } \\
\text { Umur }\end{array}$} & \multicolumn{2}{|c|}{ Kelompok } & \multirow{2}{*}{ Total } \\
\cline { 2 - 3 } & PMT & Non PMT & \\
\hline $6-11$ bulan & $146(14.4 \%)$ & $150(14.8 \%)$ & $296(14.6 \%)$ \\
$12-17$ bulan & $302(29.8 \%)$ & $313(30.9 \%)$ & $615(30.3 \%)$ \\
$18-23$ bulan & $310(30.6 \%)$ & $287(28.3 \%)$ & $597(29.4 \%)$ \\
$>=24$ bulan & $256(25.2 \%)$ & $264(26.0 \%)$ & $520(25.7 \%)$ \\
\hline Jumlah & $1014(100 \%)$ & $1014(100 \%)$ & $2028(100 \%)$ \\
\hline
\end{tabular}

Median umur anak pada kedua kelompok tidak berbeda nyata $(p=0.7223)$ yaitu 18 bulan untuk kedua kelompok. Sebagian besar anak yang diteliti masih mendapat ASI pada saat pengumpulan data yaitu $73,5 \%$ pada kelompok PMT dan $70,9 \%$ pada kelompok non PMT.

Pemeriksaan kesehatan anak menunjukkan bahwa kedua kelompok sebanding dan tidak terdapat perbedaan nyata. Sebagian besar sampel anak dalam keadaan sehat (74.8\%-75.4\%), sedang sakit ringan, bekas sakit ringan, sedang sakit berat dan bekas sakit berat dalam persentase kecil seperti terlihat dalam Tabel 2.

Tabel 2

Sebaran Anak Berdasarkan Kondisi Kesehatan

\begin{tabular}{|l|c|c|}
\hline \multicolumn{1}{|c|}{ Kesan klinis } & PMT & Non PMT \\
\hline Sehat & $711(72.6 \%)$ & $726(73.6 \%)$ \\
Sedang sakit ringan & $258(26.3 \%)$ & $256(25.5 \%)$ \\
Sedang sakit berat & $6(0.6 \%)$ & $2(0.2 \%)$ \\
Bekas sakit ringan & $2(0.2 \%)$ & $6(0.6 \%)$ \\
Bekas sakit berat & $3(0.3 \%)$ & $1(0.1 \%)$ \\
\hline
\end{tabular}

Karakteristik keluarga menunjukkan tidak ada perbedaan nyata antara kelompok case dan kontrol dalam umur ibu, tetapi terdapat perbedaan nyata dalam umur ayah, tingkat pendidikan ayah, ibu, jumlah anggota rumah tangga dan pengeluaran per kapita. Hal ini karena memang kelompok kontrol adalah keluarga bukan Gakin.
Menurut TPG, bentuk PMT dari Puskesmas ke pengelola PMT tingkat desa sebagian besar berupa bahan makanan $(47.6 \%)$ atau bahan makanan dan uang $(42.9 \%)$ dan hanya sebagian kecil berupa uang (13.0\%) seperti dalam Tabel 3. Di tingkat rumah tangga sebagian besar Gakin menerima PMT dalam bentuk bahan makanan seperti dalam Tabel 4 .

Tabel 3

Bentuk Makanan Tambahan Menurut Propinsi 
Gizi Indon 2005,28(1):40-53

Sandjaja, $d k k$.

\begin{tabular}{|l|c|c|c|c|c|c|c|c|}
\hline \multirow{3}{*}{ Bentuk Paket PMT } & \multicolumn{4}{|c|}{ Provinsi } & \multicolumn{3}{c|}{ Total } \\
\cline { 2 - 9 } & \multicolumn{2}{|c|}{ Jabar } & \multicolumn{2}{c|}{ Jateng } & \multicolumn{2}{c|}{ Kalsel } & \multicolumn{2}{c|}{} \\
\cline { 2 - 10 } & $\mathrm{n}$ & $\%$ & $\mathrm{n}$ & $\%$ & $\mathrm{n}$ & $\%$ & $\mathrm{n}$ & $\%$ \\
\cline { 2 - 10 } Uang & 4 & 30.8 & 1 & 5.0 & 2 & 9.5 & 7 & 13.0 \\
Bahan Makanan & 8 & 61.5 & 18 & 90.0 & 10 & 47.6 & 10 & 47.6 \\
Uang dan Bahan Makanan & 1 & 7.7 & 1 & 5.0 & 9 & 42.9 & 9 & 42.9 \\
\hline
\end{tabular}

Pada waktu studi dilakukan $72.1 \%$ anak masih mendapat PMT pemulihan dan sisanya pasca PMT. Pelaksanaan PMT menunjukkan keragaman baik pada kriteria sasaran, lama PMT, jenis makanan yang diberikan, nilai gizi PMT, bulan pemberian PMT. Sasaran PMT yang seharusnya anak baduta umur 6-23 bulan dari Gakin tetapi disesuaikan di daerah antara lain hanya anak baduta dari Gakin yang kurang gizi, anak baduta kurang gizi tanpa memperhatikan Gakin. Lama PMT bervariasi dari 1 sampai 12 bulan yang dimulai pada bulan berbeda. Jenis PMT yang diberikan terlihat dalam Tabel 4.

Tabel 4

Jenis-Jenis PMT yang Diberikan Menurut Daerah dan Kelompok Umur 
Gizi Indon 2005,28(1):40-53

Peranan pemberian makanan tambahan

Sandjaja, dkk.

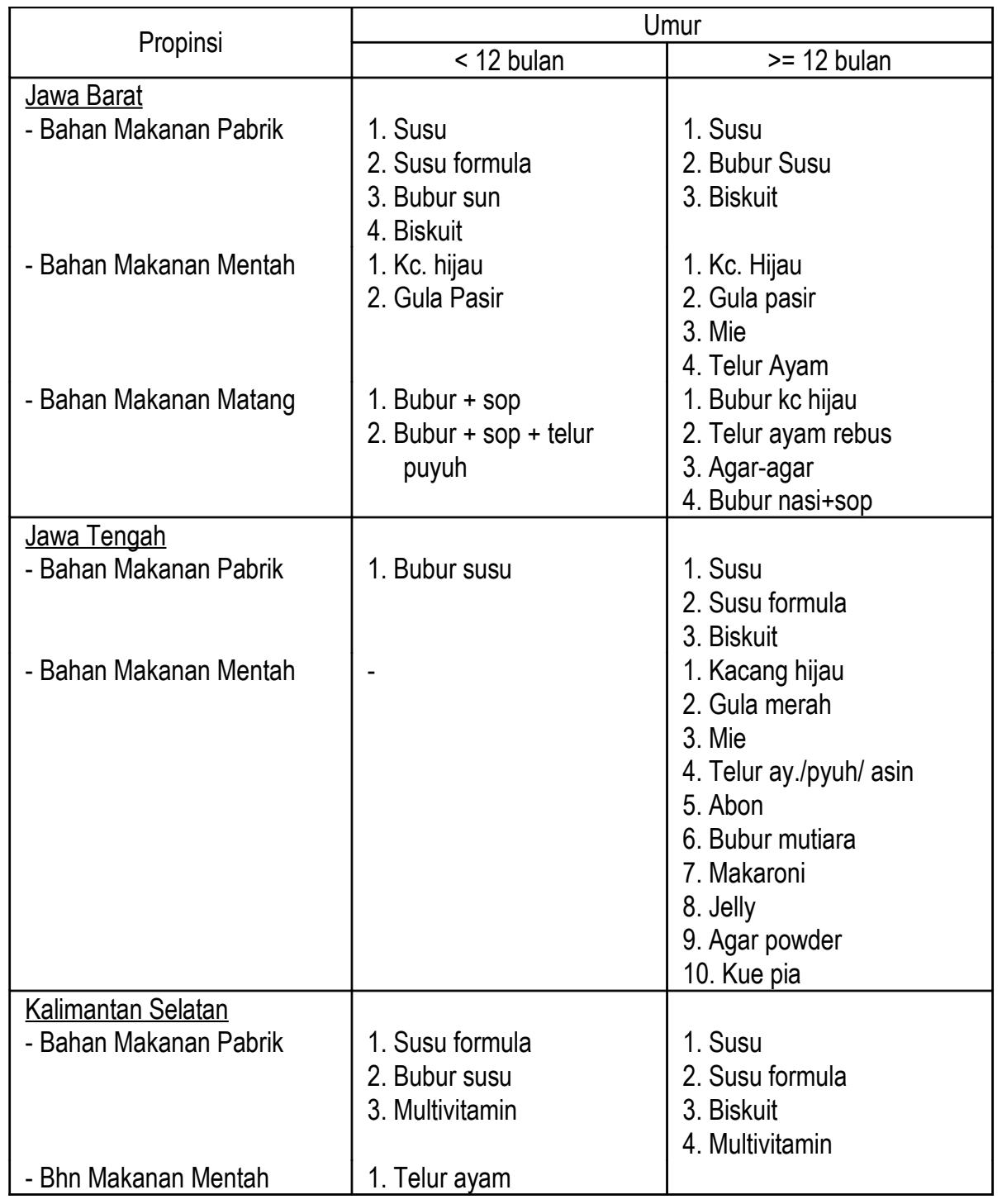

Tabel 5

Rerata dan Median Konsumsi Energi dan Protein dari Bahan Makanan PMT 


\begin{tabular}{|l|c|c|c|c|}
\hline \multirow{2}{*}{ Zat Gizi } & \multicolumn{3}{|c|}{ Provinsi } & \multirow{2}{*}{ Total } \\
\cline { 2 - 4 } Energi & Jabar & Jateng & Kalsel & \\
\cline { 2 - 4 } $\begin{array}{l}\text { - Rerata } \\
\text { - SD }\end{array}$ & 159.1 & 268.2 & 293.9 & \\
- Median & 130.5 & 157.1 & 160.1 & 230.3 \\
\hline Protein & 123.0 & 200.0 & 274.0 & 174.3 \\
- Rerata & & & & \\
- SD & 5.0 & 9.2 & 11.1 & 7.9 \\
- Median & 4.1 & 5.0 & 6.0 & 5.4 \\
\hline
\end{tabular}

Tabel 5 menunjukkan nilai rerata, standar deviasi, maupun median dari PMT yang diberikan. Nilai rerata energi dan protein PMT sebesar 230 Kkal dan 7.9 gram protein. Nilai rerata energi maupun protein masih di bawah dari yang dianjurkan untuk PMT yaitu sebesar 360-430 Kkal dan 10-15 gram protein.

Tabel 6 menunjukkan recall konsumsi makanan anak. Terlihat bahwa di luar ASI, konsumsi sehari anak masih jauh di bawah kebutuhan. Rerata konsumsi energi hanya sebesar $45.1 \%$ RDA dan protein $66.9 \%$ RDA. Tidak terdapat perbedaan konsumsi antara kelompok PMT dan Non-PMT. Hal ini menunjukkan bahwa sebagian dari PMT bukan sebagai makanan suplemen tetapi berupa substitusi.

Tabel 6

Rerata dan Median Konsumsi Energi dan Protein Terhadap RDA

\begin{tabular}{|l|c|c|}
\hline \multicolumn{1}{|c|}{ Zat Gizi } & PMT & Non PMT \\
\hline Energi (\% RDA) & & \\
Rerata & 45,1 & 45,2 \\
Median & 41,3 & 42,1 \\
SD & 26,0 & 27,1 \\
\hline Protein (\% RDA) & & \\
Rerata & 66,9 & 71,2 \\
Median & 57,1 & 59,9 \\
SD & 49,8 & 54,3 \\
\hline
\end{tabular}

Catatan: Konsumsi tsb tidak termasuk ASI

Tabel 7

Rata-rata Z-Score Dengan Beberapa Indeks Antropometri Menurut Kelompok PMT dan Non PMT

\begin{tabular}{|c|c|c|c|c|}
\hline Indeks & Kelompok PMT/Non & $\mathrm{n}$ & Rata-rata & SD \\
\hline
\end{tabular}




\begin{tabular}{|c|l|c|c|c|}
\hline Antopometri & \multicolumn{1}{|c|}{ PMT } & & Z-Score & \\
\hline $\mathrm{BB} / \mathrm{U}$ & - PMT & 1014 & $-1,6968$ & 0,9467 \\
& - Non PMT & 1014 & $-1,4048$ & 0,9831 \\
\hline $\mathrm{TB} / \mathrm{U}$ & - PMT & 1014 & $-1,5896$ & 1,1281 \\
& - Non PMT & 1014 & $-1,2954$ & 1,1380 \\
\hline $\mathrm{BB} / \mathrm{TB}$ & - PMT & 1014 & $-0,9143$ & 0,9517 \\
& - Non PMT & 1014 & $-0,7563$ & 0,9431 \\
\hline
\end{tabular}

Analisis Z-score menunjukkan bahwa rata-rata Z-score BB/U, TB/U, BB/TB menunjukkan bahwa secara umum terdapat perbedaan nyata (Uji non-parametrik MannWhitney) antara kelompok PMT dan NonPMT. Anak kelompok PMT mempunyai ratarata Z-score lebih rendah dibanding kelompok Non-PMT seperti terlihat dalam Tabel 7. Hal ini tidak terlepas dari pemilihan anak yang mendapatkan PMT seperti disebutkan di atas. Dengan demikian indeks antropometri saat ini tidak dapat digunakan untuk menilai dampak PMT karena pemilihan sasaran PMT lebih banyak ditujukan untuk anak yang menderita kurang gizi.

Status gizi anak yang dinilai dengan pengelompokan Z-score juga menunjukkan hal serupa yaitu anak kelompok penerima PMT lebih jelek dibanding kelompok kontrol. Prevalensi gizi kurang dan buruk (BB $/ U$ ) pada kelompok PMT adalah 34.0 persen dan 5.4 persen, sedangkan pada kelompok kontrol 25.8 persen dan 2.8 persen (Tabel 8).

Tabel 8

Status Gizi dan Kelompok PMT Menurut BB/U

\begin{tabular}{|l|cc|cc|cc|cc|}
\hline \multirow{2}{*}{ Kelompok PMT } & \multicolumn{6}{|c|}{ Status Gizi } & \multicolumn{2}{c|}{ Jumlah } \\
\cline { 2 - 7 } & \multicolumn{2}{|c|}{ Gizi Baik } & \multicolumn{2}{|c|}{ Gizi Kurang } & \multicolumn{2}{c|}{ Gizi Buruk } & \multicolumn{2}{c|}{} \\
\hline & $\mathrm{n}$ & $\%$ & $\mathrm{n}$ & $\%$ & $\mathrm{n}$ & $\%$ & $\mathrm{n}$ & $\%$ \\
- PMT & 614 & 60,6 & 345 & 34,0 & 55 & 5,4 & 1014 & 100,0 \\
- Non PMT & 724 & 71,4 & 262 & 25,8 & 28 & 2,8 & 1014 & 100,0 \\
\hline
\end{tabular}

$\chi^{2}=29,176 ; d f=2 ; p=0,000$

Tabel 9

Status Gizi dan Kelompok PMT Menurut TB/U

\begin{tabular}{|c|c|c|c|c|c|c|c|c|}
\hline \multirow[t]{2}{*}{ Kelompok PMT } & \multicolumn{6}{|c|}{ Status Gizi } & \multirow{2}{*}{\multicolumn{2}{|c|}{ Jumlah }} \\
\hline & \multicolumn{2}{|c|}{ Normal } & \multicolumn{2}{|c|}{ Pendek } & \multicolumn{2}{|c|}{ Sangt Pendek } & & \\
\hline & & $\%$ & $n$ & $\%$ & $\mathrm{n}$ & $\%$ & $\mathrm{n}$ & $\%$ \\
\hline - PMT & 674 & 66,5 & 258 & 25,4 & 82 & 8,1 & 1014 & 100,0 \\
\hline - Non PMT & 764 & 75,3 & 205 & 20,2 & 45 & 4,5 & 1014 & 100,0 \\
\hline
\end{tabular}

$\chi^{2}=22,479 ; d f=2 ; p=0,000$

Tabel 10

Status Gizi dan Kelompok PMT Menurut BB/TB

\begin{tabular}{|l|cc|cc|cc|cc|}
\hline \multirow{2}{*}{ Kelompok PMT } & \multicolumn{6}{|c|}{ Status Gizi } & \multicolumn{2}{c|}{ Jumlah } \\
\cline { 2 - 7 } & \multicolumn{2}{|c|}{ Normal } & \multicolumn{2}{|c|}{ Kurus } & \multicolumn{2}{c|}{ Sangat Kurus } & & \\
\hline & $\mathrm{n}$ & $\%$ & $\mathrm{n}$ & $\%$ & $\mathrm{n}$ & $\%$ & $\mathrm{n}$ & $\%$ \\
- PMT & 924 & 91,1 & 83 & 8,2 & 7 & 0,7 & 1014 & 100,0 \\
- Non PMT & 946 & 93,3 & 61 & 6,0 & 7 & 0,7 & 1014 & 100,0 \\
\hline
\end{tabular}


Sandjaja, dkk.

$$
\chi^{2}=3,620 ; d f=2 ; p=0,164
$$

Indeks TB/U menunjukkan bahwa kelompok PMT juga lebih jelek dibanding kelompok kontrol (Tabel 9). Akan tetapi indeks BB/TB menunjukkan bahwa tidak terdapat perbedaan nyata antara kedua kelompok, walaupun kelompok PMT cenderung lebih jelek seperti terlihat pada Tabel 10 .

Pertumbuhan anak sebelum, selama dan pasca pemberian PMT dinilai dari data retrospektif penimbangan berat badan. Hasil penimbangan pada kelompok kontrol pada waktu yang sama juga dikumpulkan. Hasil analisis menunjuk-kan bahwa 3 bulan sebelum masa PMT menunjukkan pola pertumbuhan yang berbeda nyata (Uji Repeated Measures of ANOVA) antara kelompok PMT dan Non-PMT. Terdapat penurunan rata-rata Z-score BB/U yang lebih tajam dibandingkan dengan kelompok NonPMT. Sedangkan pertumbuhan anak selama mendapat PMT dapat mencegah penurunan rata-rata Z-score lebih lanjut tetapi belum dapat meningkatkan status gizinya (Gambar 2). Tidak adanya perbaikan status gizi karena berbagai faktor antara lain nilai gizi PMT yang belum memadai untuk menutup kebutuhan, konsumsi makanan sehari-hari di bawah kecukupan, jangka waktu PMT yang kurang lama, PMT sebagai substitusi bukan sebagai suplementasi, sebagian PMT dikonsumsi bukan oleh sasaran, jenis PMT tidak disukai. Dengan demikian PMT berperan dalam pencegahan penurunan status gizi dan bukan berperan dalam peningkatan status gizi. Salah satu sebab penurunan Z-score sebelum pem-berian PMT yang lebih tajam pada anak Gakin diduga karena defisit konsumsi yang lebih besar pada kelompok ini. Penurunan pertumbuhan anak pada pasca PMT tidak setajam sebelum PMT karena sebagian anak masih mendapat PMT terutama yang masih menderita kurang gizi.

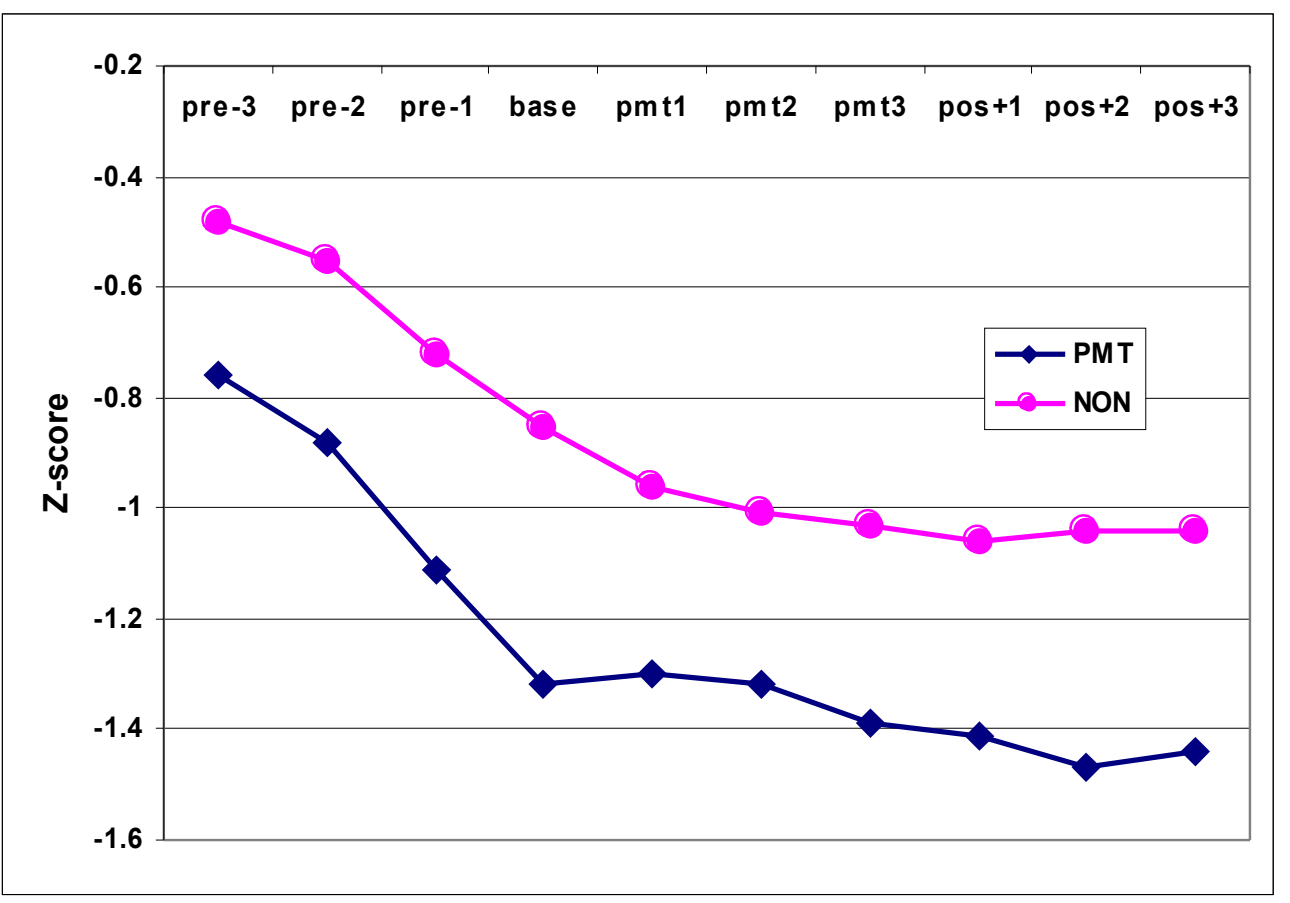

Gambar1 
Beberapa studi yang dilakukan pada bayi dan anak-anak mengungkapkan adanya asosiasi antara PMT dengan perbaikan dalam pertumbuhan, penurunan morbiditas atau perkembangan kognitif ${ }^{(7,8,9)}$. Sebagian besar studi difokuskan pada pertumbuhan sebagai satu-satunya ukuran keluaran (outcome) dari $\mathrm{PMT}^{(10,11,12)}$. Beaton dan

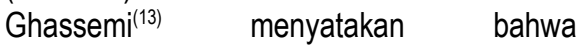
pertumbuhan fisik bukanlah satu-satunya keuntungan atau bahkan bukan pula keuntungan yang paling utama dari PMT. Peningkatan aktivitas fisik dan perkembangan aspek kognitif terjadi sebagai pengaruh $\mathrm{PMT}^{(14)}$. Pinstrup-Andersen ${ }^{(15)}$ menganjurkan perlu dilakukannya pengukuran yang lebih cermat terhadap manfaat tambahan yang diperoleh dari PMT selain dampaknya terhadap sasaran utama, seperti tingkat pendapatan dan status gizi anggota keluarga.

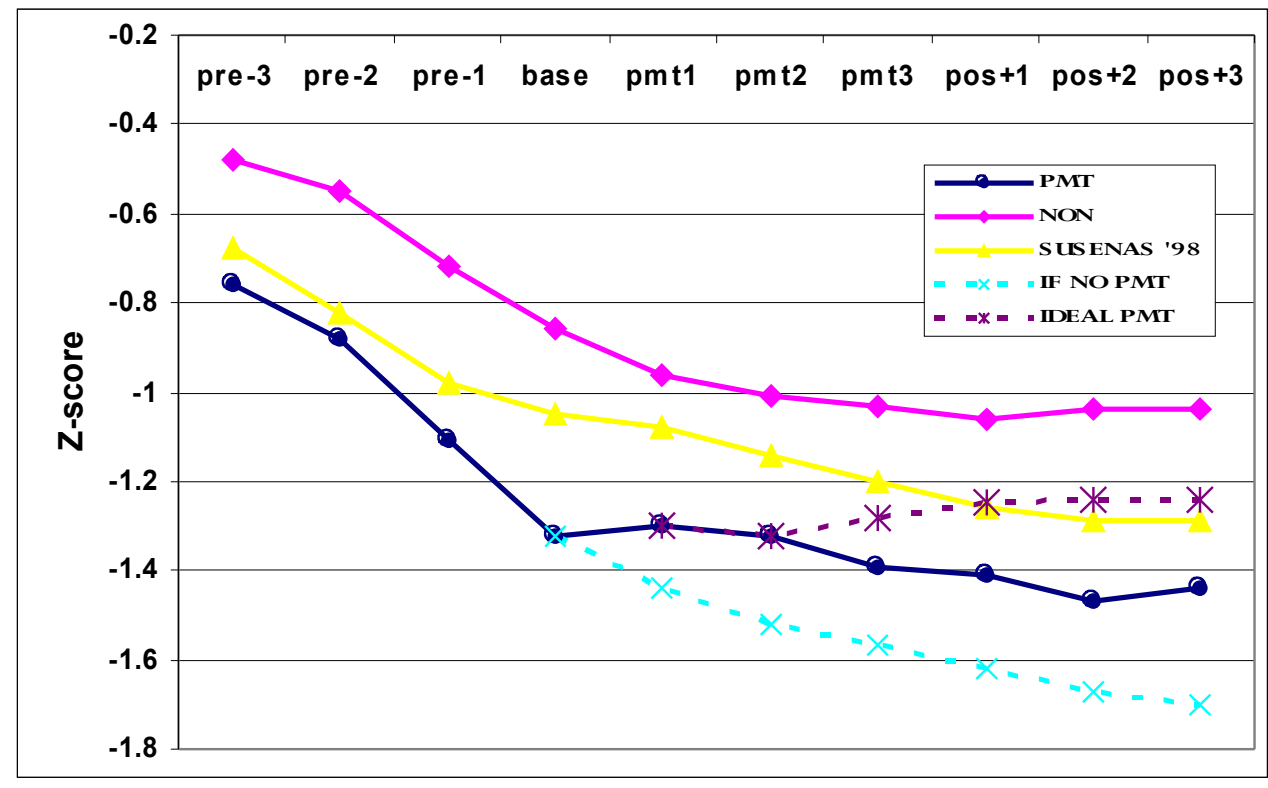

Gambar2

Pola Pertumbuhan Anak Sebelum, Selama dan Pasca PMT Dibandingkan Dengan Pola Pertumbuhan Anak Umumnya (Susenas)

Gambar 3 menunjukkan analisis lebih lanjut dari Gambar 2, berupa analisis hipotetis bila PMT tidak dilakukan pada saat krisis akan memperlebar jarak rata-rata Zskor anak Gakin. Grafik pertumbuhan tersebut juga dibandingkan dengan pola pertumbuhan anak dari data Susenas tahun 1998.

Pola pertumbuhan yang distratifikasi menurut beberapa variabel menunjukkan bahwa dampak PMT lebih nyata pada kelompok umur 12 bulan atau lebih, anak dengan status gizi kurang/buruk, konsumsi energi 50\% RDA atau lebih. Perubahan status gizi tidak berbeda pada kelompok yang masih diberi ASI/tidak, nilai gizi PMT, dan PMT dimakan sasaran sendiri atau dibagi. 


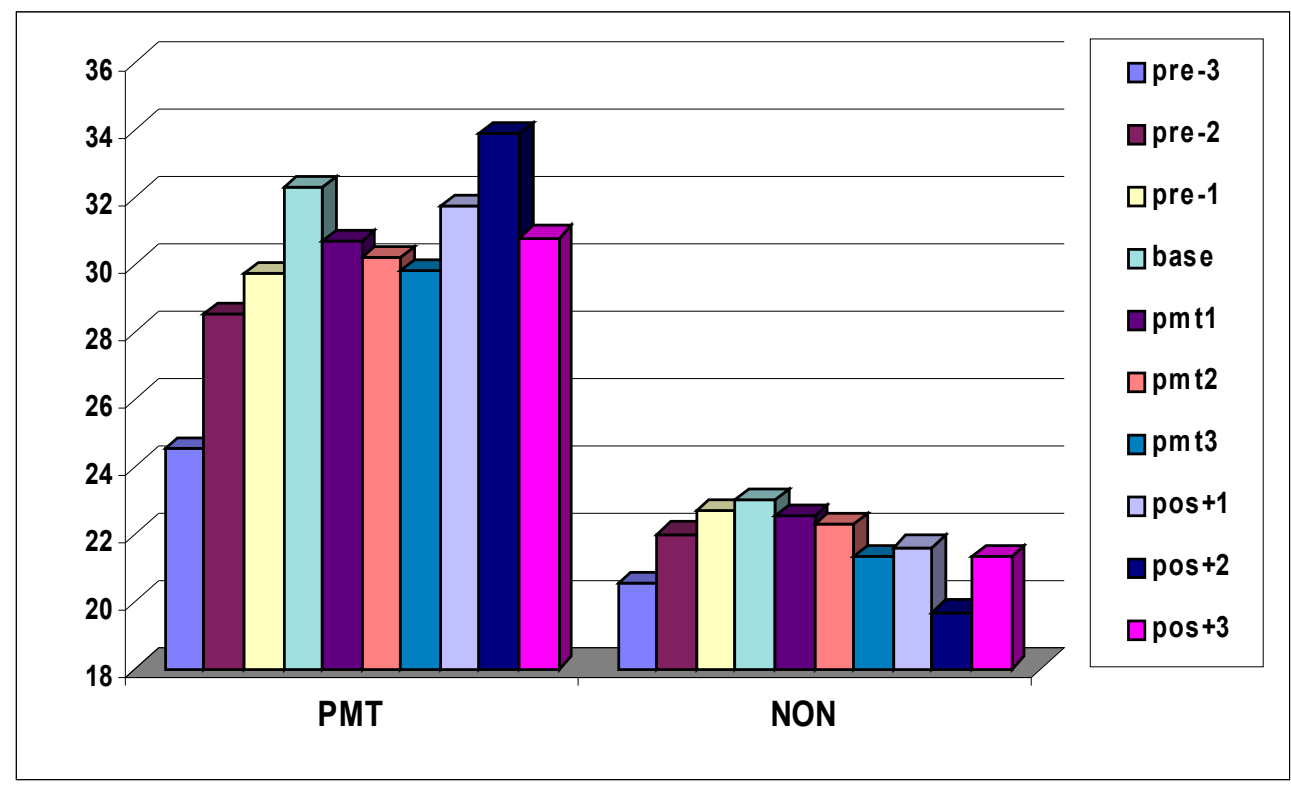

Gambar 3

Proporsi Gizi Kurang dan Buruk Sebelum, Selama dan Pasca PMT

Bila analisis pertumbuhan dilakukan dengan cara pengelompokan menurut prevalensi, perbaikan status gizi yang didapatkan karena PMT masih terlalu sedikit seperti terlihat pada Gambar 3. Bila sebelum PMT terdapat peningkatan gizi kurang/buruk sebesar $7.8 \%$ pada kelompok PMT (dari $24.5 \%$ menjadi $32.3 \%$ ) sedangkan pada kelompok Non-PMT sebesar $2.5 \%$ (dari $20.5 \%$ menjadi $23.0 \%$ ). Tiga bulan intervensi PMT menunjukkan penurunan proporsi gizi kurang/buruk sebesar $2.5 \%$ pada kelompok PMT dan 1.7\% pada kelompok Non-PMT.

\section{KESIMPULAN}

1. Pelaksanaan PMT dilakukan beragam di tingkat pelaksana. Keragaman tersebut antara lain dalam penentuan sasaran anak, umur anak, status gizi anak, lama pemberian PMT, bentuk dan bahan PMT.
2. Nilai gizi PMT masih di bawah yang dianjurkan. Rata-rata energi 230 Kkal dan 7.9 gram protein.

3. Recall konsumsi makanan anak dalam sehari hanya mencukupi $45.1-45.2 \%$ kebutuhan energi dan 66.9-71.2\% kebutuhan protein. Tidak ada perbedaan konsumsi antara kelompok PMT dan Non-PMT. Hal ini menunjukkan bahwa sebagian PMT tidak digunakan sebagai suplemen tetapi substitusi.

4. Status gizi anak penerima PMT lebih rendah dibandingkan dengan kelompok Non-PMT. Hal ini bukan disebabkan sebagai dampak PMT tetapi karena pemilihan anak yang mendapat PMT ditujukan untuk anak kurang gizi. Dengan demikian status gizi awal antara kelompok PMT dan Non-PMT sudah jauh berbeda. Perbedaan status gizi terjadi pada semua indeks yaitu $\mathrm{BB} /$ $\mathrm{U}, \mathrm{TB} / \mathrm{U}$ dan BB/TB. 
5. Pertumbuhan anak pra, selama dan pasca PMT menunjukkan terjadinya penurunan Z-score BB/U pada kedua kelompok. Hal tersebut umum terjadi pada anak di Indonesia di mana terjadi growth faltering. Tetapi penurunan Zscore lebih tajam pada kelompok PMT. $\mathrm{Hal}$ ini diduga adanya defisit konsumsi dan masalah gangguan pertumbuhan lebih banyak pada kelompok Gakin.

6. Pemberian PMT tidak dapat meningkatkan status gizi anak, tetapi mampu menahan laju penurunan Zscore yang lebih tajam sehingga dapat sejajar dengan anak kelompok NonPMT.

7. Dampak PMT dalam menahan laju penurunan status gizi lebih terlihat pada kelompok anak umur 12-23 bulan, anak dengan status gizi kurang/buruk dan konsumsi energi kurang dari 50\% RDA.

\section{SARAN}

1. Untuk dapat memperoleh dampak positif PMT hendaknya sasaran agar lebih dipertajam pada kelompok sasaran yang betul-betul memperoleh manfaat PMT yaitu anak umur 6-23 bulan dari Gakin yang menderita kurang gizi.

2. PMT hanya dapat menahan laju penurunan status gizi pada saat krisis ekonomi. Oleh karena itu perlu dipertimbangkan agar program gizi yang dapat diarahkan untuk memperbaiki status gizi anak pada saat krisis.

3. Bentuk PMT hendaknya lebih spesifik ditujukan hanya untuk kelompok sasaran dan bukan untuk yang lainnya.

\section{RUJUKAN}

1. Irawan PB, Romdiati $\mathrm{H}$. The Impacts of Economic Crisis on Poverty and Its Implications for Development Strategies. Makalah disampaikan pada Widyakarya Nasional Pangan dan Gizi
(WNPG) VII, Jakarta 29 Feb - 2 Maret 2000.

2. Widyakarya Nasional Pangan dan Gizi VII. Jakarta, 29 Febr-2 Mar 2000.

3. Latief D., et.al. Konsumsi Pangan Tingkat Rumah Tangga Sebelum dan Selama Krisis Ekonomi. LIPI, Widyakarya Nasional Pangan dan Gizi VII. Jakarta, 29 Febr-2 Mar 2000. P 159-180.

4. Sandjaja, Susilowati H. Hubungan Status Gizi Dengan Pola Konsumsi Makanan Keluarga, Karakteristik Keluarga dan Daerah : Analisis Data SUSENAS 1998. Bogor, Puslitbang Gizi, 1999.

5. Jahari AB., et.al. Status Gizi Balita di Indonesia Sebelum dan Selama Krisis (Analisis Data Antropometri SUSENAS 1989-1999). LIPI, Widyakarya Nasional Pangan dan Gizi VII. Jakarta, 29 Febr-2 Mar 2000. P 93-124.

6. Chandra, RK. Nutrition and immunity : Lesson from the past and new insights into the future. Amer.J.Clin.Nutr 53 : 1087 -1101, 1991.

7. Gopaldas T., et.al. Project Poshak, Vol. 1. New Delhi, CARE, 1975.

8. Freeman HE., et.al., Nutrition and Cognitive Development Among Rural Guatemalan Children. Amer.J.Pub.HIth. $70: 1277-1285,1980$.

9. Anderson MA, et.al. Nutrition intervention in Developing Countries: Study I. Supplementary Feeding. Cambridge, Massachusetts, 1981.

10. Chavez M., R. Huenemann. Measuring Impact by Assessing Dietary Intake and Food Consumption. In: Sahn DE., R. Lockwood, NS. Scrimshaw (eds). Methods for the Evaluation of the Impact of Food and Nutrition Programmes.Tokyo, UNU, 1984.

11. Durnin J. Measuring Impact on Physicakl Activity and Physical Fitness. In : Sahn DE., R. Lockwood, NS. Scrimshaw (eds). Methods for the 
Evaluation of the Impact of Food and Nutrition Programmes.Tokyo, UNU, 1984.

12. Martorell R. Measuring the Impact of Nutrition Interventions on Physical Growth. In : Sahn DE., R. Lockwood, NS. Scrimshaw (eds). Methods for the Evaluation of the Impact of Food and Nutrition Programmes.Tokyo, UNU, 1984.

13. Beaton GH, Ghassemi GH. Supplementary Feeding Programs for Young Children in Developing Countries. New York, UNICEF, 1979.
14. Rutishauser IHE, R. Whitehead. Energy Intake and Expenditure in 1 to 3 Year Old Ugandan Children Living in a Rural Environment. Brt.J.Nutr. 28 : 145-152, 1972.

15. Pinstrup-Andersen P. Assuring Food Security and Adequate Nutrition for the Poor. In Bell DE, Reich MR (eds). Health, Nutrition, and Economic Crises: Approaches to Policy in the Third World. Auburn House Publishing, Massachusetts, 1988. P 147-176. 